\title{
MICHAEL GOVE'S HERITAGE: SCHOOL GOVERNANCE REFORM
}

\author{
Richard Riddell*
}

\section{INTRODUCTION}

This article examines the nature and effects of the radical reforms to English school governance since 2010, the year in which a Coalition Government, led by the Conservative Party, came to power in the UK, and Michael Gove was appointed Secretary of State for Education for England, a post he occupied for four formative years of Education reform. These governance reforms were part of a much wider programme of change, arguably fundamental in the sense that they have affected the classroom experiences of students directly. This programme encompassed changes to the curriculum, the assessment of children (and, by proxy, teachers and schools), the initial training and assessment of teachers and, eventually, school inspection, with the most recent revised Ofsted Inspection Framework governing inspections in use from September 2019 (Ofsted 2019).

Nevertheless, governance changes provide the framework through which all educational change in the future can be conceived, considered, interpreted, implemented and realised with students. So although all the above changes are identified with Gove, the changes to governance, often still badged as 'academisation', may be argued to be the most fundamental and the basis for considering future change and, indeed, Gove's heritage. No one policy maker controls the complete process of change and its development, of course, one of the features of 'complexity', and it is argued here that the methods of realising governance reform in England have severely constrained future choices of direction.

\section{ORIGINS OF 'ACADEMISATION': THE ARGUMENT MADE HERE}

'Academisation' itself was not invented in 2010 - it was first mooted in 2000 (Blunkett, 2000) and became a legal status in 2002 - but its policy use and access were expanded dramatically from that date. Fundamentally it became the chosen instrument for changing the educational polity more generally - the wider organ-

\footnotetext{
* Dr Richard Riddell MA MPhil PhD PGCE FHEA
} 
isational arrangements within which schools operate and develop. It literally transformed the physical landscape of schooling (Simkins, 2015). As academisation accelerated, it engendered new organisations from its own structural logic - Multi-Academy Trusts (MATs) - drawing on, but changing in the process, previous forms of school alliance, informal and formal, such as soft and hard federations, trusts and then academy chains (Riddell, 2016). By the same structural logic, MAT development was accompanied by the deliberate, planned and structural decline of local authorities' (LAs') Education role: stated intentions to change were repeatedly unfulfilled, and ambitions to remove school improvement powers (DfE, 2016) left incomplete. At the same time, there were unrepentant and unremitting strategic reductions to government grant to LAs administered by the Department of Communities and Local Government as it was then (Riddell, 2019), compounded by the budget reductions from 'losing' academies. There were $49.1 \%$ in real terms between 2010-11 and 2017-18 (NAO, 2018), with no more than a third of this capable of being recouped through Council Tax.

The engineered declining capabilities of LAs and MAT development together necessitated new bureaucracies at regional level - it was not possible to supervise the rapidly increasing numbers of academies and MATs from London. So regional DfE offices accumulated more powers, though largely advisory to the Secretary of State, and took on roles previously exercised nationally. This in turn necessitated the appointment of new senior officials to lead this work, termed, appropriately enough in public market terminology, 'Regional Schools Commissioners'. They did the commissioning work for a time too.

This overall policy assemblage is therefore dynamic as it is still developing and changing under its own logic. In terms of numbers of schools, there were some 9,000 academies at the beginning of the current Covid pandemic, far more than the third identified by the National Audit Office in 2018, but academisation was strategically complete at secondary level before then (Riddell, 2016; 2019). These schools were now 'run' (but see below) by about 1500 MATs of varying sizes (Carter with McInerney, 2020). And a further 214 (LA-) 'maintained' schools 'converted' during 2020/21 as the pandemic raged (Whitaker, 2020).

But this assemblage is also unstable, in classic fashion in many contemporary forms of governance - 'neoliberal' if you will - as illustrated by Ball and Junemann (2012). The instability in the schools polity derives from what has become the now central importance of the powers and remit of the regional DfE Offices to making local school ecosystems work, especially where support for schools 'at risk' is being considered, the implementation of some intervention being planned and MAT development and expansion is being considered. Because these powers derived from a highly centralised authority - with key officials responsible to a national 
minister (not always elected) - their nature, balance and local implementation can also be changed centrally and abruptly.

This is just what the Secretary of State did in 2018 (Riddell, 2019; Carter with McInerney, 2020), with consequences for the articulation of local school polities. The strategic importance of local polities for continuing improvement has been known for some time (Fullan, 1993; 2019). Briefly, there has to be some process around schools for identifying weakness and aiding and sustaining improvement if national ambitions for standards continue, and the 'ratchet' on schools moves up a notch on a regular basis (as occurred after the 2019 revised Ofsted inspection framework). But this also applies to 'outstanding' schools that have achieved national benchmarks, but wish to develop particular aspects of their teaching, sometimes requiring some expertise available elsewhere. These schools can only go to the market for this advice and consultancy if one exists, and post-LA this market capacity in local polities remains very uneven. The author's most recent interview evidence (for Riddell, 2019) suggests there is little capacity anywhere for secondary schools.

The instability will most likely continue in the 'mixed economy' of schools, which will be with us for some time. To add to complexity, the English schools polity includes other organisations besides RSCs/DfE and MATs with separate and different accountability structures and priorities: not the least elected Councils, some led by politicians of the same party as current ministers, Ofsted with its own strong regional offices, and of course the churches and faith groups.

As this instability is structural, governance also will remain fluid for the conceivable future as English governments continue to govern on a highly centralised basis, making for possible further shifts in the future and continuing uncertainty for school leaders, irrespective of the stability of their own trajectories. Furthermore, although rooted in notions of school standards, tinged with historic distrust of local authorities, the national schools polity in England leaves many questions not only unanswered, but unrecognised and now structurally incapable of being addressed, irrespective of how important citizens might consider them to be. The very nature of the organisations that have developed through the process of governance change severely restrains the nature of the response.

\section{HOW THE CURRENT SCHOOLS' POLITY UNFOLDED}

For a full understanding, it is important to understand the detail of how the current state of play arrived. No policy maker at any level begins with a tabula rasa for the realisation of policy ambitions, of course (eg Gale, 2003). As both Michael Gove and David Cameron, as respectively shadow education secretary and leader of the opposition, engaged politically before the 2010 election with (certainly) parent and (probably) school leader groups they had the legal framework of academies in 
mind for potential applications for the new Free Schools, and granting greater autonomy to schools and their leaders. The Academies Act 2010 accordingly changed the means of access to the status by which bodies, though the approval process would remain the centralised responsibility of the Secretary of State.

The original (City) Academies, open from 2002 onwards, and sponsored to begin with by various local organisations including business, were part of an highly centralised strategy to tackle school 'failure', especially in urban areas because of an increasing government disenchantment with the capabilities of LAs doing so. Failure was measured then as now by an 'Inadequate' Ofsted judgment, requiring 'special measures' and poor student outcome data. Academies were funded through an agreement made directly with the Secretary of State, for which they are (after a series of changes) now held accountable by the Education and Skills Funding Agency (Riddell, 2009; 2016), an 'executive agency sponsored by the Department for Education' (GOV.UK).

The perceived advantages of such a centralised arrangement to Government was that the DfE had direct control over the process of improvement in the school, without having to spend time dealing with intermediaries such as local authority officers, advisers and inspectors who were considered by Gove as part of the 'Blob' (Young, 2014), along with university academics and others. The Department could send in its own staff chosen by itself. These oversight functions, as part of the national and now regional school improvement strategies, continue though are now supervised more locally (since 2014) by the nine RSCs (Riddell, 2016; Carter with McInerney, 2020).

The changes enacted in 2010 did allow groups of parents, teachers and community groups to make proposals directly to the Secretary of State (now via RSCs) for new schools that better met their expressed needs or approaches than that provided by the LA - to set up their own 'Free Schools'. This were intended to diversify and disrupt local schools markets, providing challenge for the schools that remained (DfE, 2010). Many of them, from the author's own experience are quite outstanding - others less so.

Much more significant in terms of numbers, the governing body of any (LA-) maintained school, as they routinely began to be termed, with an 'outstanding' verdict could decide by a simple majority to apply to the Secretary of State for academy status. Many did, without any rigorous local process of consultation, thus becoming 'convertor' academies as opposed to the original 'sponsored' ones arising out of some sort of intervention. This also had significant funding advantages for a time, including for capital works, and many applications were made for pragmatic reasons, as LAs declined, rather than a desire to shake free (Riddell, 2016).

But these changes also represented a politically directed and accelerating movement away from former LA 'control' of schools in England - once the Labour 
Government lost its trust in LAs to change stubborn under-performance, it has not returned to governments since of any political colour. A complete status change for all schools was stated explicitly as a political objective in 2015 (Cameron, 2015), with the completion date of 2022 set the following year (DfE, 2016), but this target was abandoned shortly afterwards. This is why the 'mixed economy' of schools is likely to remain.

Cameron's speech to the Conservative Party conference that year was explicitly framed in very anti-local authority terms, envisaging a future where no schools would be responsible to LAs at all. Even though the target was abandoned, for many practical reasons, there is no doubt that this distrust remains with both ministers and their officials, from the author's most recent interviews. This will certainly colour any future changes to the polity.

Academically, the development of academisation has been much studied at various stages of the process, for example: Academies Commission (2013), Boyask (2013), Coldron et al (2014), Courtney at al (2020), Cousin (2018), Greany (2014, 2015, 2018), Lord et al (2016), Simkins (2015), and many more, from a variety of standpoints. Many of these studies have been relatively small scale, comprising a few schools or handful of local authorities, but more recently, the outcomes were published of a national Nuffield-funded project (Greany and Higham, 2018), using 47 school case studies across four localities, with a particular focus on the Self-Improving Schools System (SISS) - the stated objective of Government policy according to them - and how these stated policy aspirations have shaped and formed the current polity. It was accompanied by a detailed data analysis (Bernadetti et al, 2018).

\section{THE DEVELOPMENT OF MATS AND THE NATURE OF THE ORGANISATIONS THAT HAVE EMERGED}

The (policy) 'arguments for' academisation process have varied, with different arguments deployed on different occasions, which might be expected. Originally rooted in national school improvement policies, behind the backs of LAs, the process clearly changed when schools voluntarily became convertor academies: they were already achieving above national expectations in terms of student data and Ofsted inspection. They had already (been) improved, consensually or not (Riddell, 2016; Simon et al, 2020). The argument made originally was that status change would allow better intervention, but significantly also allow school leaders just to get on with it themselves, with the help of other 'people like them'. In any case, the standards argument became more and more difficult to sustain as the number of convertors began to vastly outnumber the number of sponsored academies (Connelly et al, 2014). This argument by itself is rarely aired now in policy 
terms, reflecting the almost complete academisation of secondary schools and the routinisation of attending one as a student becomes eleven.

Now the 'argument' - where indeed there even is one - has shifted to what (only) academisation can make possible, or indeed is required after a direction to convert in response to an RSC review. As noted, MATs developed from previous informal and formal governance arrangements and are legally based on the model for school Trusts set up by 2006 Education Act. 'Pairing schools', often a higher performing school with a lower performing one, became more and more of a feature from the early 2000s, many originally 'brokered' by LAs and supported by funding and LA staff maintained to discharge their responsibilities towards standards. More and more, these staff were brought in on a time limited nature from other successful schools. The idea behind 'brokering' in simple terms is that the leader(s) of the more successful school, supported by others, would spend time working in the other to help develop its own improvement trajectory, passing on directly some of their more successful experience.

With the academisation process accelerated by Gove and his officials after 2010, many of these 'other' successful schools providing support and challenge to their less fortunate peers were by now academies. They looked directly to the DfE for their own support and direction - naturally enough when time and attention are inevitably limited. So a national scheme for accrediting these outstanding leaders, quality assuring their involvement in other schools, developed piecemeal before 2010 now blossomed into the current array of National, Local, and Specialist Leaders of Education (and of governance).

Carter and McInerney (2020) in their account set out the problems very clearly with the earlier informal arrangements, and the nature of federations before MATs. With more than one governing body involved and different community aspirations and composition, the time of accredited, outstanding school leaders, even with a centrally allocated budget, could be unnecessarily spent on gaining agreement before actually doing anything to enable a weaker school to improve. Their own time might also be limited because of the restricted budget for their support work and the fact that their own schools wanted them back, not unreasonably.

For schools requiring improvement - limited for now to those with unsatisfactory data and inspection outcomes (all schools can arguably always do some things better) - the solution was obvious: more permanent arrangements. The more successful school (a convertor) would themselves sponsor their fellow schools where asked, and would set up funded, formal organisations with the staff, time and resources to work permanently with poor performing schools. This policy idea provided the genesis for the development of MATs as the one accepted form for this work, often termed 'chains' in the early days.

Beginning as voluntary associations in the early years after the 2010 reform, 
as the new circumstances were adjusted to, primary schools - hitherto largely 'loyal' to LAs - also began to associate and convert in larger numbers, joining or opening MATs as LAs were forced to offer less and less by way of effective services or support. A third of primaries had converted by the start of the pandemic (Greany, 2020). However, the phase of voluntary association and MAT consolidation and expansion is largely over.

This then was the multi-fold impeccable structural logic that compelled first, academisation, then setting up or joining MATs to pool resources and give central MAT staff more sustained time for better collaboration, support and development. Thus MATs have become the central organisational feature of the English schools polity, and the ones that must be studied (Simon et al, 2020) to understand how the system now articulates. But these developments have by no means guaranteed success (Greany and Higham, 2018) and the construction of local polities that may seem less than desirable.

Currently, MATs vary in size and reach from the very local to the national another feature of organisational instability. The largest number of MATs still have two to five schools, enabling extra but limited support capacity, though many single free-standing academies remain (SATs as they are now referred to) as a result of decisions made earlier in the 2010s. As Simkins (2015) remarked, they are a prominent feature of the current system. Their free standing nature makes their continued development more risky unless outside organisations (such as the DfE) are able to fund development time for them. New proposals for SATs no longer receive approval through the RSC process and RSCs interviewed by the author have the objective of persuading them, even when there isn't a problem, to join larger MATs.

DfE staff known as 'Education Advisors' and 'Delivery Teams' were gradually repurposed for the continuing conversion and development work, the former sometimes on a consultancy basis, and assigned pragmatically to the developing regional offices. The Regional School Commissioners (RSCs), drawing on reports by these staff, are now advised about the development of new MATs and academy conversions by headteacher boards (HTBs), three quarters of whom are elected every four years from existing academy heads who, as Coldron et al (2014) are 'well-positioned' in the developing polity. As Greany and Higham (2018) point out, these school leaders, of originally individual high performing schools, are among the greatest beneficiaries of the governance arrangements as they have developed since 2010. They are key to making local polities work, which have become more and more hierarchical.

But the organisational form of MATs - school trusts - needs to be understood to understand both their strengths and limitations. MATs are non-profit companies registered at Companies House, with a small number of founding 'members' akin 
to shareholders in a private company. They appoint the Board of Trustees, which then determines governance relationships with individual schools, which may have local governing bodies (LGBs) with varying powers, or none (all DfE, 2019). The nature of the LGB, whatever their powers, is largely that of a committee of the board, whose prime responsibility, depending on the MAT, is to hold their own leadership team to account and maintain relations with parents and, sometimes, the local community. The Board makes decisions behind closed doors and is not obliged to publish or circulate its minutes. Most do not - 'secrecy' has been a common word used by CEOs and others interviewed by the author over the past few years. With some MATs responsible for over 60 schools, inevitably their holding to account of the MAT's senior leadership team centres on bottom line figures and trajectories of student outcomes, a focus made easier by the minority of educationalists on most Boards.

The CEO and leadership team of the MAT line and performance manage the headteachers of its individual schools. The LGB, where it exists, may have an input to this process, but the author uncovered one headteacher who felt she had had little involvement in setting her own objectives (Riddell, 2019). One of the original goals of 2010 was to increase the autonomy of school leaders (DfE, 2011), but accumulating evidence belies this (Greany and Higham, 2018; Riddell, 2019) and to an extent this has changed the traditional view of the headteacher being wholly responsible to a governing body for a school's 'curriculum and conduct' (Lord et al, 2017). Leaving aside the issue of managing its leaders, MATs occupy varying places on the centralisation spectrum with regards to both the curriculum (some MATs have introduced detailed, week by week curricula from Key Stage 1-4) and teaching, with some MATs requiring lessons to be 'delivered' (literally) in specific ways, with prescribed techniques and approaches.

\section{THE POLITY AS A WHOLE}

The importance of the local schools polity to sustain school development and improvement - traditionally the LA in England, but single-focus district school boards in the US and elsewhere - was rehearsed earlier. Understanding how the practice of teachers with their students could best be supported and developed has been ongoing for many years (see eg Riddell, 2003). What emerged during the 2000s was the need for timetabled joint work between teachers in each other's classrooms, not just their leaders, and where possible from different schools. Hargreaves (2012) termed this 'Joint Practice Development' (JPD) that could be sustained between funded schools partnerships and at best, outside accountability structures, with teachers not being instructed to improve. Taking this as a starting 
point in a complex argument, the question for governance is then what form of local polity can best provide it. MATs, which are hierarchical and not partnerships at all (Greany and Higham, 2018), do not do this, although Greany and Higham did observe some JPD during their research.

Broadly speaking, MATs are not accountable in the same way public services traditionally are. Ofsted have undertaken a number of 'evaluations' since 2017 whether they could be inspected or not was eventually ruled out by ministers. Their outcome data, including inspections, is desk top reviewed at least annually by both the RSCs and geographically focused 'delivery teams' and all the LAs the author has visited over the last eight years. If these data are not showing particular risks, then the MAT's accountability is confined to (sometimes) annual meetings behind closed doors of their Board Chair and CEO with the RSC and staff. If individual schools are identified as at risk from desk top reviews, then the RSC will contact the CEO, not the headteacher.

RSCs were until recently informed about particular MATs through unpublished visit reports - often not seen by the MATs concerned and considered timeconsuming 'parallel inspection' - and were given advice behind closed doors by their headteacher advisory boards. The announcements made by the Secretary of State referred to earlier (Hinds, 2018) dramatically changed this and with it the balances of power in local polities. Under party political pressure, he restricted the use of the advisers which in turn led to a rethink of RSC roles (Riddell, 2019), re-emphasising the importance of brokering support (usually from MATs), not primarily commissioning it or sending in their own staff, and working to 'develop the wider school improvement system' with LAs, The Teaching Schools Council (which has assumed new significance) and Dioceses where needed. In a review of how school improvement strategies would be developed and implemented regionally (TSC, 2018), it was frankly stated that RSCs themselves could no longer carry out or oversee school improvement work.

Accordingly, school improvement work was to be undertaken by a range of participants, including MAT staff, supported by TSC officials. The agreement and allocation of time and support would be take place through a new network of regional, sub-regional and local authority level boards (TSC, ibid), building on both previously established committees to oversee the agreement and implementation of the 'Strategic School Improvement Fund' (another time limited central allocated development budget) and the school partnerships investigated by Hatcher (2014), Riddell (2019) and Greany (2020). These LA level boards are all largely professional-dominated, include all the above listed organisations, MAT CEOs as well as maintained headteachers, and again meet behind closed doors. Some LAs still did not have them in 2019 (Riddell, ibid), despite pressure from 
RSCs. This could form the sort of 'glue' role for LAs described in Greany (2020) in the future, beyond the scope of this article.

In summary, as has been argued, the centralised legitimacy of power over the collection of local schools polities in each RSC region, with the potential for future rebalancing of function and role by the Secretary State, entail stability for only so long as he or she wishes it. And what happens in individual schools in a MAT will similarly remain stable as long as there are not risky school data and the Board is kept happy. But the continuing uneven development of MATs, with differing geographical spreads by size and phase that have remained a focus of RSCs since Educational Excellence Everywhere (DfE, 2016), taken with the variety of approaches taken to their own governance and therefore the nature of their schools, mean there will be no arrival point or fixed state for an academised school structure.

Given also the historic variety in the way that LAs have seen their role in the past (Simkins et al, 2015) and what seems to be a recent widespread reconsideration of their roles as they are considered important partners of government once again, the English schools 'system' will remain variegated, as perhaps it has always been, with any nationally driven change having different results locally. This makes it extremely difficult to be clear about national directions for school governance and organisation in the longer term, or at least reliably so, and the to-be-settled roles of RSCs, CEOs, headteachers and LA. Instability will remain a key characteristic; the paradox of this opaque centralised system, created by Michael Gove, is diversity.

\section{A footnote on free schools}

Although free schools have continued to be proposed and opened, advised and supported by the arm's length charitable organisation, the New Schools Network, it is difficult to argue that they have played a strategic role in the developing schools polity nationally or locally. In their 'pure' original form, intended to be local schools market disruptors, they have always remained in small numbers, though the extremely high quality of some of these new schools, very often in areas of high deprivation, should not be overlooked (Riddell, 2016). But the free school proposal mechanism, with much stricter and more detailed requirements than in the early days of the reform, is now the only way to open a new school. With the need to respond to increasing pupil numbers, the number of 'ordinary' mainstream schools, mostly proposed by MATs, that are in fact free ones has far overtaken the 'disruptors'. 


\section{HAS ANY OF THE GOVERNANCE REFORM ACTUALLY WORKED?}

To conclude briefly, one of the aspects of the different approach taken to schooling from 2010 was the 'recentring' of schools (Simon, 2010) in Government-driven attempts to not only improve student outcomes, but achieve wider policy outcomes such as widening social mobility. By that is meant before 2010 the Labour Government viewed school reform as part of a range of wider policy interventions on health, economic well-being and poverty as these also impact on not only what students are able to achieve in school but how they progress and hence wider societal effects. The basic approach to improving social mobility under the Coalition government (Cabinet Office, 2011) was centred on attainment in education.

The wider societal results have been in fact, not to over-analyse them, disappointing. Social Mobility is now going backwards and has been for a number of years (Social Mobility Commission, 2020, and many earlier reports). Poverty by all accounts is increasing (Bourquin et al, 2019) in an unstable labour market. A further related long standing aspiration of 'closing the gap' in attainment between disadvantaged students (usually measured by entitlement to free school meals and more recently for Pupil Premium funding) has been disappointed: this gap at age 16 has been increasing year on year since 2014 and, after early gains, is now doing the same at age 11 (Hutchison et al, 2020).

On measuring attainment itself, it is arguably quite difficult to compare outcomes at 16 before and after the introduction over two years a new grade structure at GCSE: the old minimum standards grade of $\mathrm{C}$ is now spread over two grades, the new 4 and 5. This leads to presentation of results by MAT Boards as Basic 9-5 and Basic 9-5, where 'basic' refers to English and Maths. Further, expectations of school outcome are now expressed predominantly in terms of 'progress' as measured from entry to the particular school. This is the 'Progress 8' (in eight subjects) measure for secondary schools. A P8 score relates to a statistically derived single number score in comparison with the average score of all schools. Above average is represented as more than zero; less than average a negative number. These scores are comparatively recent, but now form the basis for school targets and intervention in response to at risk data. The measure did not exist before 2010 .

One final point. The stated purpose of the local school polities in RSC regions is now absolutely confined to school improvement, just as MATs are - better outcomes. One CEO interviewed for Riddell (2019) stated that this was what 'it was all about'. But schools are not, and have never been, single purpose monofocal organisations focusing on the bottom line: they need to meet and provide effectively for students with a wide range of special educational and other needs, 
including giftedness, which might very well prove significant barriers to both their happiness and their progression to the next stages of their lives. They need to introduce, celebrate enrol their students in the cultural and heritages of the populations they cater for. They need to play a part with other organisations, public and private, in realising the economic health, wellbeing and happiness of their various communities, and contribute to local and national prosperity. This is a long list: schools are not merely organisations devoted to finding technical solutions to a narrow range of measurable student outcomes.

But the governance arrangements outlined here allow of no public discussion whatsoever of how any of these things are done, leaving aside any input to any public (or indeed behind closed doors) decisions about change for the better. In this sense, schools have become both depoliticised (Wilkins, 2016) and monofocal in the public eye. One of the most striking findings from the author's most recently published research (Riddell, 2019) was that there is no open public forum, as part of any pubic body, where improvements can be discussed and acted on to provision for the most needy children, for example, address school transfer and admissions problems, consider the shape of new schools or now, most important, how post-pandemic reconstruction should take place after the compounding of disadvantage during the lockdown implemented during the pandemic (eg Andrew et al, 2021). English schooling has ceased to be part of any recognisable democracy and why, certainly, at least upper secondary education - probably more - has now stagnated (Rogers and Spours, 2020) without much prospect of renewal.

\section{REFERENCES}

Academies Commission (2013) Unleashing Greatness: getting the best from an academised system, London: RSA.

Andrew, A., Cattan, S., Costa Dias, M., Farquharson, Kraftman, L., Krutikova, S., Phimister, A. and Sevilla, A. (2021) Family time use and home learning during the Covid 19 lockdown, London: Institute for Fiscal Studies.

Ball, S. and Junemann, C. (2012) Networks, New Governance and Education, Bristol: Policy Press.

Bernadetti, D. and Rutt, S.; Greany, T. and Higham, R. (2018) Multi-Academy Trusts. Doo they make a difference to pupil outcomes? Supplementary statistical analysis to Greany and Higham, London: UCL IoE Press; Slough: NFER.

Blunkett, D. (2000) Transforming Secondary Education, London: Social Market Foundation

Bourquin, P, Cribb, J, Waters T and Xiaowei Xu (2019) Living Standards, poverty and inequality in the UK: 2019 London: IFS 
Boyask, R (2014) Nuanced understandings of privatisation in local authorities' services to schools. Management in Education 29 (1) 35-40

Cabinet Office (2011) Opening Doors, Breaking Barriers: A strategy for social mobility London: Cainet Office

Carter, D with McIrnerney, L (2020) Leading Academy Trusts. Why some Fail, but most don't. Woodbridge: John Catt Educational Ltd

Coldron, J., Crawford, M., Jones S. and Simkins, T. (2014) The restructuring of schooling in England: The responses of well-positioned headteachers, Education Management, Administration and Leadership 42 (3): 387-403

Connelly, R., Sullivan, A. and Jerrim, J. (2014) Primary and Secondary Education and Poverty, London: Institute of Education.

Courtney, S. and McGinty, R. (forthcoming) System Leadership as depoliticisation: Reconceptualising educational leadership in a new Multi-Academy Trust, Education Management and Leadership

Cousin, S (2018) System Leaders in England: Leaders of a profession, or instruments of government Educational Management, Administration and Leadership I Printing of the SIS 1-18 DOI: 10.1.1177/1741143217751726

Department for Education (DfE) (2011) The Importance of Teaching, London: the DfE.

Department for Education (2016) Education Excellence Everywhere, London: DfE.

Department for Education (2019) Governance Handbook for Academies, MultiAcademy Trusts and Maintained Schools, London: DfE.

Fullan, M. (1993) Change Forces: probing the depths of education reform, London: The Falmer Press.

Fullan, M (2019) Nuance: why some leaders succeed and others fail, London: Sage/Corwin.

Gale, T. (2003) Realising Policy: The who and how of policy production, Discourse: Studies in the cultural politics of education 24 (1): 51-65.

Greany, T (2015) More fragmented, and yet more networked: Analysing the responses of two Local Authorities in England to the Coalition's 'self-improving school-led system' reforms London Review of Education 13 (2) p125-143

Greany, T (2015) The Self-Improving System in England: A review of Evidence and Thinking Leicester: ASCL

Greany, T (2018) Sustainable improvement in multi-school groups' Research report DFE-2017/038 London: DfE

Greany, T and Higham, R (2018) Hierarchy, Markets and Networks. Analysing the 'self-improving schools-led system agenda in England and the implications for schools. London: UCL IoE Press

Greany, T. (2020) Place-based governance and leadership in decentralised school 
systems: evidence from England, Journal of Education Policy https://doi.org/10 $.1080 / 02680939.2020 .1792554$.

Hargreaves, D (2012) A Self-Improving Schools System: Towards Maturity London: NCSL

Hutchison, J., Reader, M. and Akhal, A. (2020) Education In England: Annual Report 2020, London: Education Policy Institute with the Fair Education Alliance and Unbound.

Lord, P., Wespeiser, K., and Harland, J. (2016) Executive Headteachers: What's in a name? Full Report of Findings, Slough, Birmingham and London: NfER, NGA and TFLT

Ofsted (2019) The Education Inspection Framework, Manchester: Ofsted

Riddell, R (2003) Schools for Our Cities. Urban Learning for the Twentieth Century. Stoke-on-Trent: Trentham Books

Riddell, R. (2009) Schools in Trouble Again: A critique of the National Challenge (2008), Improving Schools 12 (1), p71-80.

Riddell, R (2016) Equity, Trust and the Self-Improving Schools System. London: UCL IoE Press/Trentham Books

Riddell, R (2019) System Fluidity in English Schools Governance: Reflections on the Implications for Senior Leaders of Closed Hierarchies. Management in Education 33 (9) p126-133

Rogers, L. and Spours, K. (2020) The great stagnation of upper secondary education in England: A historical and Systems, Perspective British Educational Research Journal 46 (6): 1232-1255.

Simkins, T. (2015) School Restructuring in in England: New school configurations and new challenges, Management in Education 29 (1): 4-8.

Simon, C., James, C. and Simon, A. (2021) The Growth of Multi-Academy Trusts in England: Emergent Structures and the Sponsorship of Underperforming Schools, Education Management Administration and Leadership 49 (1): $112-127$.

Social Mobility Commission (2020) Monitoring social mobility 2013-2020: is the government delivering on our recommendations? London: the Social Mobility Commission.

TSC (2018) A regional operating framework for school improvement Teaching Schools Council

Whittaker, F (2020) Covid-19: MATs should use resources to help 'vulnerable' school recover, says Herrington Schools Week, $17^{\text {th }}$ November

Young, T (2014) Prisoners of the Blob; Why education experts are wrong about nearly everything, London: Civitas. 